\title{
Permian plants from the Chutani Formation (Titicaca Group, northern Altiplano of Bolivia): I. Genera Pecopteris and Asterotheca
}

\author{
CARLOS E. L. VIEIRA ${ }^{1}$, ROBERTO IANNUZZI ${ }^{1}$, MARGOT GUERRA-SOMMER ${ }^{1}$, \\ ENRIQUE DÍAZ-MARTÍNEZ ${ }^{2}$ and GEORGE W. GRADER ${ }^{3}$ \\ ${ }^{1}$ Departamento de Paleontologia e Estratigrafia, Instituto de Geociências, UFRGS \\ Cx. Postal 15.001, 91501-970 Porto Alegre, RS, Brasil \\ ${ }^{2}$ Centro de Astrobiología (CSIC-INTA), Carretera a Ajalvir, km 4, 28850 Torrejón de Ardoz, Madrid, Spain \\ ${ }^{3}$ Department of Geology, University of Idaho, Moscow, ID, 83844-3022 U.S.A. \\ Manuscript received on February 27, 2003; accepted for publication on September 9, 2003; \\ presented by Diogenes A. CAMPOS
}

\begin{abstract}
Fossil plants belonging to the morphogenera Glossopteris, Pecopteris and Asterotheca were collected from the upper part of the Chutani Formation (Titicaca Group), near the town of San Pablo de Tiquina, on the southeastern shore of Lake Titicaca (northern Altiplano, Bolivia). Here we report the analysis of fern-type foliage found at this location. Three species of pecopterid fronds are identified: Pecopteris dolianitii Rohn and Rösler, P. cf. P. cadeadensis Rohn and Rösler, and P. cf. P. pedrasica Read. All these species are typically found in Permian deposits of the Paraná Basin in southern Brazil. Despite the poor preservation of the material, a fertile specimen could be studied and was determined as Asterotheca sp. The paleoenvironmental and paleoecological implications of this new find are briefly analyzed.
\end{abstract}

Key words: Altiplano of Bolivia, Permian, Pecopteris, Asterotheca.

\section{INTRODUCTION}

The presence of coal beds and plant remains in the Upper Paleozoic beds of Bolivia has been known since the $19^{\text {th }}$ century. The Paleozoic fossil record of Bolivia is known for its completeness and taxonomic diversity when compared to other South American countries. Branisa (1965), in his classical work on Bolivian guide fossils, related the Bolivian Late Paleozoic plants to the Gondwanan flora. This relationship was not proven by systematic studies of the floral elements but the location of Bolivia in western Gondwana makes this assumption likely. The present work confirms the presence of "it Glos-

Correspondence to: Roberto Iannuzzi

E-mail: iannuzzi@if.ufrgs.br sopteris Flora'" in Bolivia by the study of Permian floras and establishes their relation with the rest of Gondwana.

\section{GEOLOGICAL SETTING}

The studied samples were collected from the upper part of the Chutani Formation (Titicaca Group), near the town of San Pablo de Tiquina, by the southeastern shore of Lake Titicaca, in the northern Altiplano of Bolivia (Figure 1). The local stratigraphy consists of mixed carbonate and siliciclastic rocks with volcanic and volcaniclastic interbeds, all belonging to the Lower Permian (Kungurian) to ?Lower Triassic Chutani Formation (Figure 2). These rocks form part of a wide fold within one of the thrust sheets 


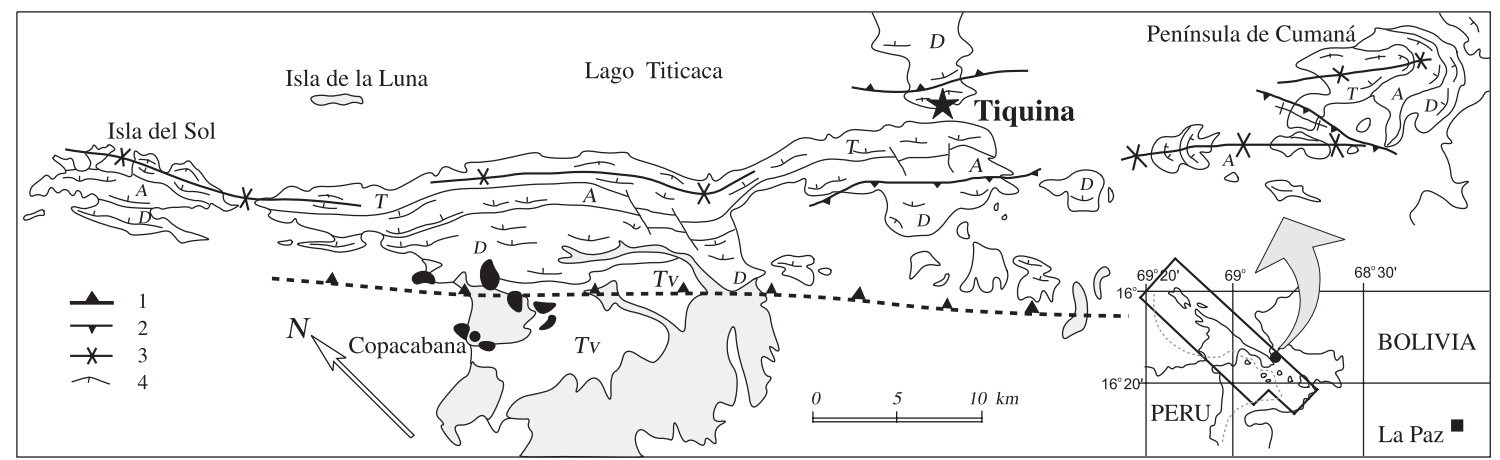

Fig. 1 - Location of the study area at the SE end of lake Titicaca, and main geological units (modified after Ascarruntz and Radelli 1964). Code: Devonian sedimentary units (D), Ambo Group (A), Titicaca Group (T), Tertiary clastic deposits (gray), subvolcanic intrusions (black) and Tertiary volcanic deposits (Tv) associated to the Coniri Fault (1), other thrusts and backthrusts (2) related to the Coniri Fault, sinclines (3), and structural contour of beds (4).

of the Huarina Fold-and-Thrust Belt (Sempere et al. 1990), an imbricate thrust system mostly vergent to the SW. The sampled beds themselves are dipping to the SW and form part of a continuous sequence between two thrust faults: one of them located to the $\mathrm{NE}$, in contact with Devonian units (indicated at the base of the stratigraphic column depicted in Figure 2), and the other one located to the SW and covered by the lake.

The rocks where the fossil plant specimens were found consist of thin beds of silty dolostone interbedded with mudstone, marl and finegrained sandstone (Figure 2). The environment of deposition proposed for the Chutani Formation consists of a semiarid tidal flat with mixed carbonate and siliciclastic deposition. There is also input from a volcanic source, as indicated by the presence of tuffs and fine-grained volcaniclastic sandstones (probably reworked pyroclastic deposits), and by the basaltic lavas overlying the Chutani Formation, in the transition to the Tiquina Formation red beds.

The Early Permian (Kungurian) to ?Early Triassic age assigned to the Chutani Formation is mostly based on its correlation with the Vitiacua Formation, which crops out in central and southern Bolivia (Díaz-Martínez 1995, 1996, 1999, SuárezSoruco and Díaz-Martínez 1996). Beltan et al. (1987) and Suárez-Riglos and Dalenz (1993) suggested a latest Triassic (Late Norian) age for the up- per Vitiacua Formation in southern Bolivia, based on the existence of Monotis (Entomonotis) subcircularis. None of these two works provide any information on the precise stratigraphic location of the samples, although similar fossil remains are frequently found towards the top of the unit throughout the region (Sempere et al. 1992). A Middle Triassic minimum age is established for the Vitiacua Formation by the oldest (not reset) $\mathrm{K}$-Ar radiometric age obtained from overlying basalt lava flows in southern Bolivia. If true, this age for the upper part of the Vitiacua Formation would be older than the pteriomorphid bivalve in Bolivia than in New Zealand, where it is well dated as late Norian. The following additional paleontological evidence in the Vitiacua Formation suggests a Late Permian and Early Triassic age for this unit (Sempere et al. 1992): (a) the palynoflora includes both Late Permian northern European species (Lueckisporites virkkiae, Klausipollenites schaubergeri) and Permian Gondwanan forms (Lueckisporites taeniaeformis, Corisaccites alutas, Weylandites magnus), and (b) vertebrate (chondrychthyes and ostheichthyes) remains include Birgeria sp. (a genus present throughout the Triassic) and Coelacanthus cf. C. granulatus (a Late Permian species). Small fish teeth were also found in the Tiquina stratigraphic section, below the plant remains (Figure 2), but they were not identified. On the other hand, Sempere et al. (1992) correlates the 


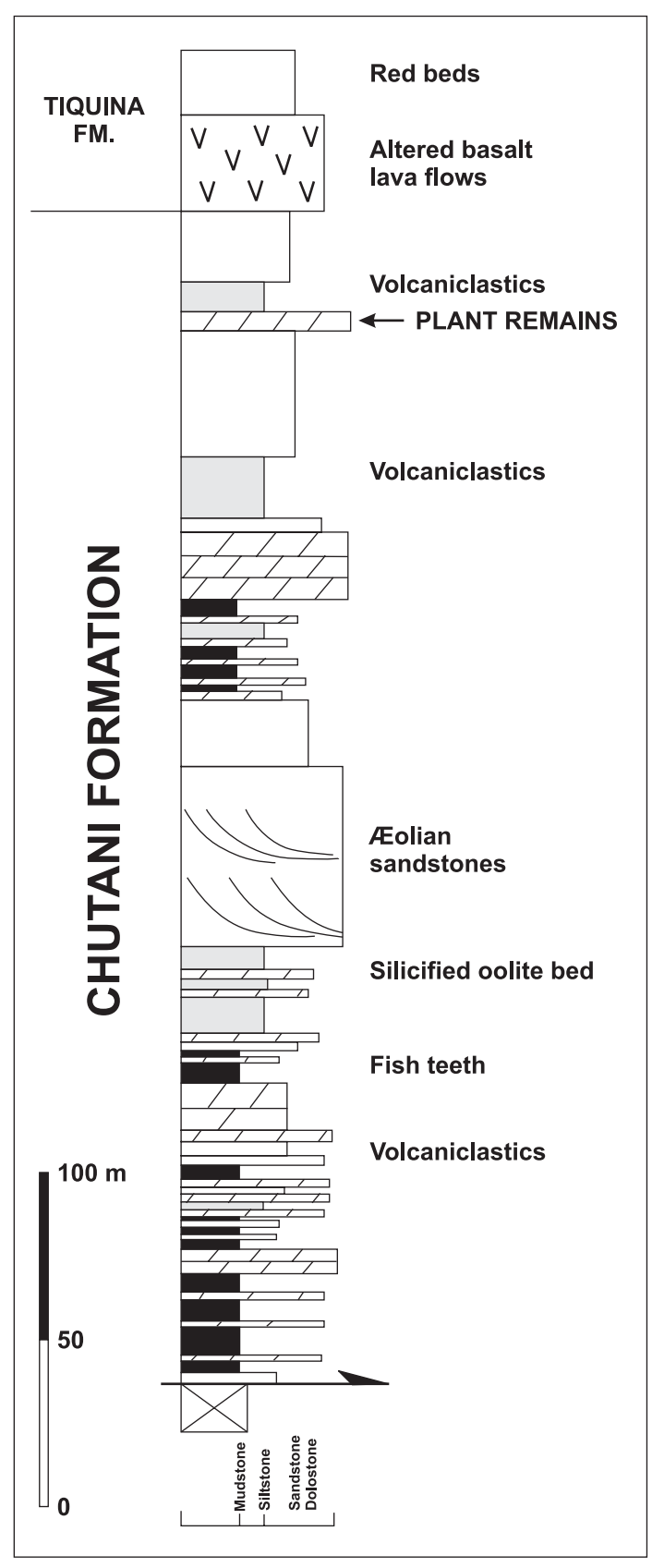

Fig. 2 - Simplified stratigraphical column of the Late Paleozoic succession northeast of San Pablo de Tiquina.

Vitiacua Formation, equivalent of the Chutani Formation for central and southern Bolivia, with the Irati Formation of the Paraná basin of Brazil. The Irati Formation is considered Kazanian in age based on palynological evidence (Daemon and Quadros

\section{0, Arai 1980, Marques-Toigo 1991).}

In the Altiplano region of western Bolivia, the Chutani Formation conformably overlies the Copacabana Formation, which is well dated as Late Carboniferous-Middle Permian (Early BashkirianKungurian), based on conodonts, foraminifera, calcareous algae, bryozoans, and other invertebrates (Merino and Blanco 1990, Mamet 1994, 1996, Dalenz and Merino 1994, Sakagami and Mizuno 1994, Isaacson et al. 1995, Sakagami 1995, Mamet and Isaacson 1997). In conclusion, the lower boundary of the Chutani Formation cannot by older than Kungurian and the upper limit cannot by younger than Mid or Late Triassic, according to correlation to similar units in central and southern Bolivia (Oller and Sempere 1990, Soler and Sempere 1993).

\section{MATERIALS AND METHODS}

In 1996, three of the authors (RI, EDM, GWG) collected fossil plants belonging to the morphogenera Glossopteris, Pecopteris and Asterotheca. The fossils were found to the NE of San Pablo de Tiquina, a small town on the SE shore of Lake Titicaca (western Bolivia), where ferryboats cross the Strait of Tiquina to the Copacabana Peninsula. The fossil site is located approximately $80 \mathrm{~m}$ up-hill from the town's cemetery. The leaves of Glossopteris were described by Iannuzzi et al. (2004) and form the second part of this study. The fronds of Pecopteris and Asterotheca were found as impressions and authigenic replicas (i.e., external moulds/ casts) on brownish yellow, hard, compact, silty dolostone. The specimens are fragmentary, and sometimes stained by iron oxide in the case of impressions. All studied specimens are listed below and curated at the Museu de Paleontologia of the Departamento de Paleontologia e Estratigrafia of the Universidade Federal do Rio Grande do Sul (code prefix: MP-Pb).

\section{PALEOBOTANICAL RESULTS}

Pteridophylla (INCERTAE SEDIS)

Genus Pecopteris (Brongniart) Sternberg, 1825

Pecopteris dolianitii Rohn and Rösler, 1986

Fig. 3A, B, C 
Material: MP-Pb 3390, 3391, 3393, 3394, 3395, 3396, 3397, 3399, 3402.

Description: Sterile pinna fragments without preserved apex and margin. The fragments measure 22.8 to $43.1 \mathrm{~mm}$ in width, and 17.9 to $24.2 \mathrm{~mm}$ in width. The pinna rachises are robust, 2.2 to $3.0 \mathrm{~mm}$ in length, and have numerous hair scars. The pinnules emerge alternately from the pinna, very close to each other, with insertion angles between $60^{\circ}$ and $90^{\circ}$, and 2 or 3 pinnules per centimeter. There is no space between subsequent pinnules, but they are not imbricated. Pinnules are digitiform with rounded apex and straight margins, measure 6.7 to $11.0 \mathrm{~mm}$ in length and 2.6 to $5.2 \mathrm{~mm}$ in width, with 2.1 to 2.6 length/width ratio. The midveins are straight, very conspicuous, dichotomizing near the apex, and have hair scars. The lateral veins arise from midvein alternately or suboppositely, in angles between $34^{\circ}$ and $57^{\circ}$, and the resulting branches do not reach the margins in straight angles. Lateral veins may bifurcate once, but never more. When present, the bifurcations occur at the last third of lateral veins length, near pinnule margins.

Comparison: The presence of rachis and robust veins in the studied specimens significatively reduces the number of Late Paleozoic pecopterid forms to compare with. Amongst known South American species (Read 1941, Frenguelli 1953, Dolianiti 1957, Menendez 1957, Archangelsky and De La Sota 1960, De La Sota and Archangelsky 1962, Arrondo 1967, Rigby 1968, Rösler 1972, Bortoluzzi 1975, Boureau and Doubinger 1975, Herbst 1976, Cazzulo-Klepzig 1978, Anderson and Anderson 1985, Rohn and Rösler 1986, Odreman and Ricardi 1992, Oliveira 1996, Archangelsky et al. 1999, Vieira and Iannuzzi 2000), Pecopteris dolianitii Rohn and Rösler (1986), described from Late Permian deposits in the Paraná Basin (Estrada Nova and Rio do Rasto formations), is the most similar to the Bolivian specimens. The material here analyzed presents the same pinnule shape, vein pattern, and disposition on the pinna, as those of the species described by Rohn and Rösler (1986). However, certain characteristics in a few of the studied specimens (pinnule length and width, rachis length of the pinna) present small discrepancies in terms of absolute size. Furthermore, the Bolivian specimens present their pinnules quite close to each other, although never overlapping or coalescing at the base, as described for some specimens of $P$. dolianitii. The few differences observed are not considered taxonomically significant, so the Bolivian material may be included in P. dolianitii.

\section{Pecopteris cf. P. cadeadensis Rohn and Rösler 1986}

Fig. 3D, E

\section{Material: MP-Pb 3389b}

Description: Sterile pinna fragment, $15.9 \mathrm{~mm}$ in length and $14.9 \mathrm{~mm}$ in width. The pinnae rachis measures $1.5 \mathrm{~mm}$ in width, and has a longitudinal groove and some hair scars. Its apex and base were not preserved, so the overall shape of the pinna is not known. Pinnules are attached to the rachis with alternate pattern, three pinnules for centimeter, with angles between $58^{\circ}$ and $87^{\circ}$, and are coriaceous in appearance. The pinnula basal margins are joined while the median and apical margins are free. The pinnule apexes are oblong and the pinnule bases are attached to the rachis by their entire width. The pinnule surfaces are slightly folded resulting in a concave/convex appearance. Pinnules are 6.2 to 7.5 $\mathrm{mm}$ in length and 3.3 to $3.9 \mathrm{~mm}$ in width, with a 1.9 to 2.2 length/width ratio. A conspicuous and robust midvein arises from the rachis and ascends straight towards the apex before dichotomizing once. Lateral veins emerge alternately from the midvein, according to a catadromic pattern, without decurrence, with angles of $65^{\circ}$ in average. The lateral veins bifurcate once near the pinnule margin to bring two divergent straight branches. There are approximately ten lateral veins in each pinnule side, and two lateral veins per millimeter.

Comparison: The slight decurrence of the mid veins of pinnules in specimen MP-Pb 3389b resembles the species P. dolianitii Rohn and Rösler (1986), although the shape of the pinnules is slightly different. Pinnula turns up to the pinna apex slightly, and veining presents thick nerves and short interneural 


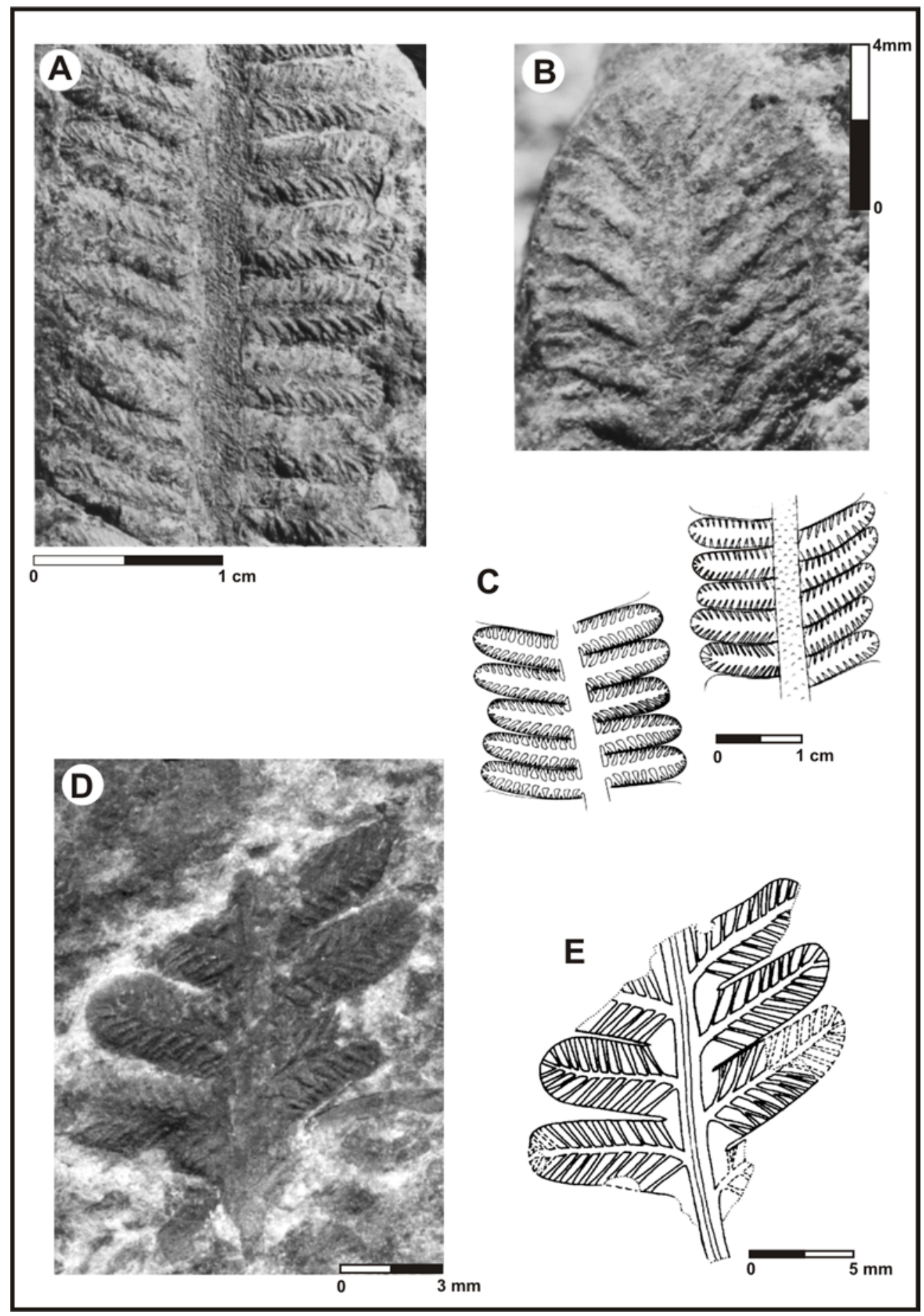

Fig. 3 - Pecopteris dolianitii: (A) pinnae fragment of MP-Pb 3393 showing a high proportion of leaf area occupied by a hugh venation; (B) detail of a pinnule of MP-Pb 3395 showing a convex leaf surface and a hugh venation; (C) drawings of MP-Pb 3395 and MP-Pb 3386, respectively. Pecopteris cf. P. cadeadensis: (D) pinnae fragment of MP-Pb 3389b showing its hugh venation; (E) drawing of MP-Pb 3389b. 
space, suggesting that the specimen under study resembles the species $P$. cadeadensis Rohn and Rösler (1986) from the Rio do Rasto Formation (Late Permian of the Paraná Basin). However, the amplitude of pinnule insertion angles $\left(58-87^{\circ}\right)$, the minimum length and width of pinnules, and the angle between secondary and main vein $\left(65^{\circ}\right)$ are different. Therefore, considering the scarce and fragmentary character of the analyzed Bolivian material and the small differences, we opted for an open classification.

\section{Pecopteris cf. P. pedrasica Read 1941}

Fig. 4A, B

\section{Material: MP-Pb 3392}

Description: Sterile pinna fragment, $16.0 \mathrm{~mm}$ long and $19.9 \mathrm{~mm}$ wide. The pinna rachis is $2.3 \mathrm{~mm}$ wide, with numerous hair marks. Its apex and base are not preserved. The pinnules are alternately attached to the pinna rachis at $58^{\circ}$ to $85^{\circ}$ angles, with a density of two pinnules per centimeter. The pinnules are attached to the rachis by their entire base. They have rounded oblong apex and lobate margins, particularly in the cathadromic basal region (giving a false wing aspect to the pinna). The longest pinnula is 9.0 $\mathrm{mm}$ long, width average is $6.4 \mathrm{~mm}$, and length/width ratio is 2.1. Midveins are straight and undivided until near the apex, from where they bifurcate once, show soft decurrence, are very robust, and reach a width of $1.5 \mathrm{~mm}$ at pinnula base. Lateral veins arise with a soft decurrence, sub-oppositely, and with $50^{\circ}$ to $60^{\circ}$ angles, with at least one bifurcation. One or two additional bifurcation can be developed between the two first bifurcation branches, resulting in groups of three or four veins which reach the margin in almost right angles. Nine lateral vein groups occur on each side of the pinnula, with a density of one per millimeter.

Comparison: Amongst the pecopterid species analyzed (Read 1941, Frenguelli 1953, Dolianiti 1957, Menendez 1957, Archangelsky and De La Sota 1960, De la Sota and Archangelsky 1962, Arrondo 1967, Rigby 1968, Rösler 1972, Bortoluzzi 1975, Boureau and Doubinger 1975, Herbst 1976, Cazzulo-Klepzig 1978, Anderson and Anderson 1985,
Rohn and Rösler 1986, Odreman and Ricardi 1992, Oliveira 1996, Archangelsky et al. 1999, Vieira and Iannuzzi 2000), the most similar to the studied specimen is $P$. pedrasica $\operatorname{Read}(1941)$, originally described from the Rio Bonito Formation (Lower Permian of the Paraná Basin). However, it differs from Read's (1941) species in the pinnule's mid vein diameter, which is much more robust in the Bolivian specimen. More complete and better preserved specimens would be needed for a more precise identification.

Class Filicopsida

Order Marattiales

Family Asterothecaceae

Genus Asterotheca Presl 1845

?Asterotheca sp.

Fig. 4C, D, E

Material: MP-Pb: 3389a

Description: Fertile pinna fragment $54.4 \mathrm{~mm}$ long and $17.2 \mathrm{~mm}$ wide, with general oblong shape (although neither the apex nor the base have been preserved). Pinna rachis is $1.6 \mathrm{~mm}$ wide and has a slight longitudinal groove. Pinnules are attached to pinna rachis by their entire base, subopposite to alternately inserted at angles between $87^{\circ}$ to $98^{\circ}$, and with margins very close to each other without overlapping. Pinnules are 6.7 to $7.4 \mathrm{~mm}$ long, 2.6 to 3.2 $\mathrm{mm}$ wide, and 2.1 to 2.8 length/width ratio, with oblong apex and straight and undivided margins, and approximately 3.2 pinnules per centimeter. Pinnules have conspicuous, straight and undivided midveins, and synangia, with 4 or 5 fusiform sporangia, attached on their surface half way between midvein and margin.

Comparison: Despite being represented by just one specimen, quite fragmented and without vein pattern, the material presents enough characteristics to relate it with to the genus Asterotheca (according to Boureau and Doubinger 1975). The round structures around a central point and preserved as external molds over the pinnule impressions, are here interpreted as fused sporangia arranged in a synangium. The reproductive structures of radial type, together 


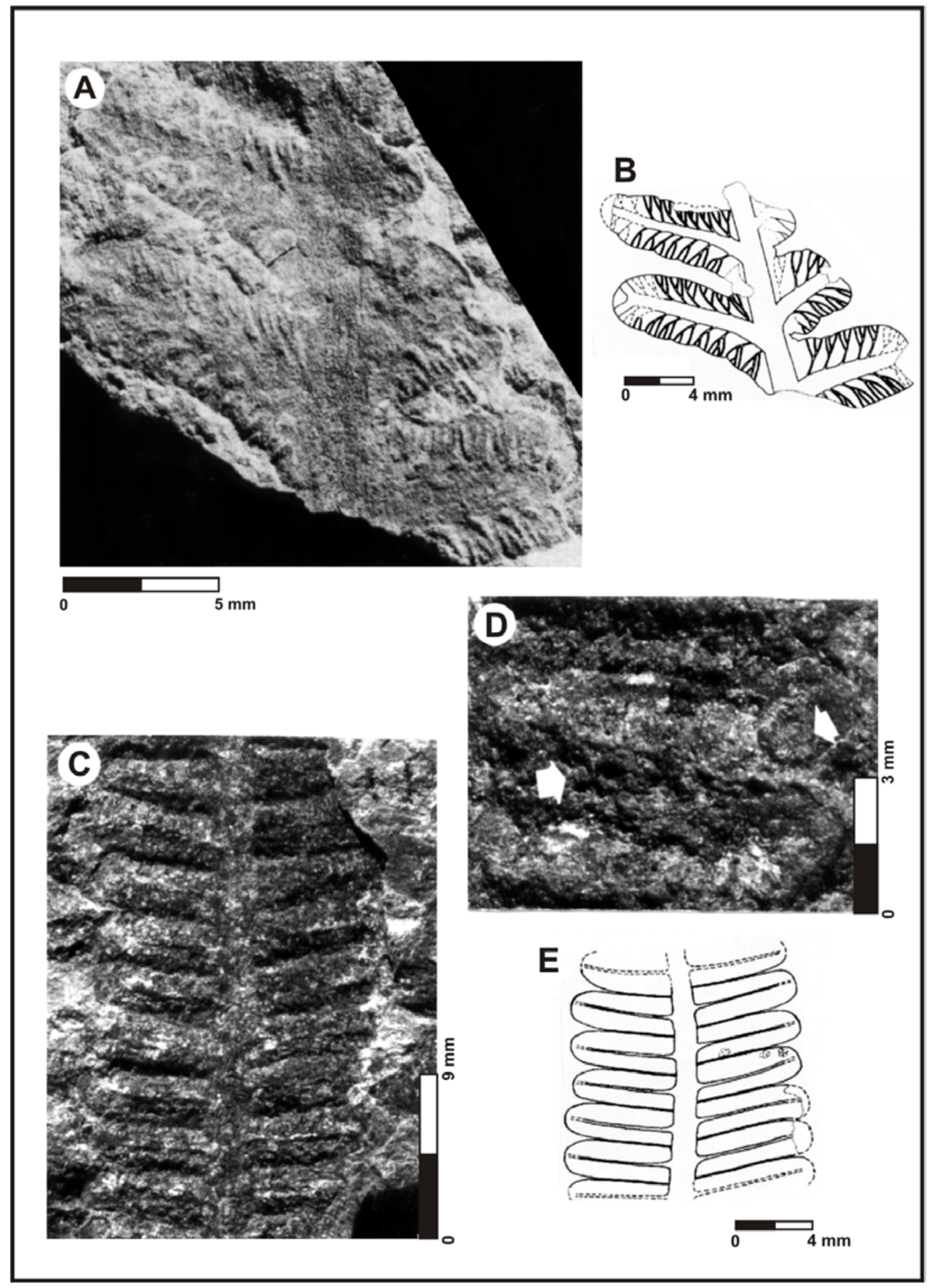

Fig. 4 - Pecopteris cf. P. pedrasica: (A) pinnae fragment of MP-Pb 3392 showing the hugh venation and a very small limbic area; (B) drawing of MP-Pb 3392. Asterotheca sp.: (C) and (D) pinnae fragment of MP-Pb 3389a with abaxial leaf surfaces and some of the presumed sinangia (arrows); (E) drawing of MP-Pb 3389a showing some of the presumed sinangia. 
with the pecopterid pinnules allow to classify the specimen as Asterotheca sp.

\section{DISCUSSION}

\section{PALEOENVIRONMENT}

The semiarid environment suggested by the tidal dolostones and eolian sandstones in the Chutani Formation, as well as the overlying red bed deposits, agree with the overall tendency towards warmer and drier climates in the Bolivian region of western Gondwana during the Late Paleozoic, as a result of its latitudinal displacement towards lower latitudes since the Carboniferous (Díaz-Martínez et al. 1993). The plant remains here studied, and the thin coal beds in the underlying Copacabana Formation, indicate the presence of coastal areas with vegetation during the Late Carboniferous and Permian, a time of suggested tropical semiarid conditions (Díaz-Martínez 1996, 1999, Díaz-Martínez et al. 2000a,b). The vegetation seems to be a low diversity flora from estuarine marshlands and wetlands associated with river discharge into the basin. Their presence is probably related with the better preservation of paralic environments during periods of relative sea-level rise.

\section{Paleoecology}

Most of the pecopterids present in the floral assemblage of the Chutani Formation described herein, share the following set of common features: pilose cover, thick lamina, curved surface of pinnules and striae, and furrows and/or carenae along the axes.

The presence of numerous hairs may be inferred from the scars preserved in the form of impressions left over the pinna rachis surface. A lower evapotranspiration rate is observed in hairy plants compared to those that are "naked" but this physiological phenomenon does not necessarily indicate water stress adaptation, as it can be a response to a phytophagy (Larcher 1995). In spite of this, a high pilosity of plants is commonly considered xeromorphic and/or halomorphic adaptation to water stress environments (Cutter 1987, Spicer 1989, Barthel and Weiß 1997, Givnish 1995).
Many specimens have pinnules curved toward the abaxial face showing a three-dimensional aspect to its impression, with concave parts and convex counterparts. In both cases, thin and distinct lines can be seen surrounding the margins, like a pinnule contour. These small lines correspond to the impression of pinnule thickness, and indicate the existence of relatively thick laminas. Rohn and Rösler (1986) suggest the same interpretation for this taphonomic feature found in material from the Paraná Basin. The presence of thick laminas represents a classic response of plants to avoid dehydration, as it protects the mesophyll against drying (Cutter 1987, Spicer 1989, Björkman and Demmig-Adams 1995, Givnish 1987, 1988, 1995, Lösch and Schulze 1995, Barthel and Weiß 1997). Furthermore, curving of pinnule surface observed in several specimens creates different orientations of part of the leaf lamina to solar radiation: one dorsal and two laterals. These planes reduce the effective area of the lamina that is exposed to direct sunlight. In these cases, mid veins tend to look bigger, although in absolute terms their dimensions are not significantly larger than those measured on pecopterids from other regions and/or paleoenvironments. In some cases, the midveins fill a larger area in pinnules dorsal planes, reaching more than one third of the pinnule (specimens MP-Pb 3392 - Pecopteris cf. P. pedrasica, MP-Pb 3394 - P. dolianitii). Pinnule surface curvature can also be found in moist environments but even in these cases it is related to water stress (physiological drought) because water may not be available to plants due to acid soil leaching, soil freezing, etc. (Björkman and Demmig-Adams 1995, Lösch and Schulze 1995, Larcher 1995). Finally, the presence of furrows and carenae along the rachis, verified in some of the studied specimens, provides different axial planes for direct insolation, creating microenvironments with lower temperature, and protecting the plant from the water stress originated by the high temperatures and direct sunlight (Gartner 1995, Givnish 1995). Each of these features is an obvious xeromorphic response due to physiological drought, environmental drought or both. In other words, each of these features taken alone 
does not allow recognizing which environment is responsible for their xerophytic nature. Nevertheless, taken as a whole these features allow recognizing an environment with strong water deficit where high luminosity and temperatures may have contributed to this condition. In fact, the presence of evaporites and other related paleoclimatic proxies indicates a tidal flat depositional system with semiarid paleoenvironmental conditions at the time of deposition of the studied strata (Isaacson and DíazMartínez 1995, Sempere 1995, Suárez-Soruco and Díaz-Martínez 1996, Díaz-Martínez 1999). According to the most probable paleogeographic and paleoclimatic interpretations (Morel and Irving 1981, Scotese and McKerrow 1990, Díaz-Martínez et al. 1993, Isaacson and Díaz-Martínez 1995), during time deposition, the study area was located within the tropical-subtropical belt, with increased temperatures and solar radiance.

It has been suggested that Pteridophyta, together with pteridosperm groups, were pioneer and abundant elements in the recolonization of paleoenvironments frequently modified by volcanic activity. Once established, they perpetuated themselves for long periods of time at those localities, making it difficult, or even inhibiting, their substitution by new plant assemblages (Arens 1991, DiMichele and Hook 1992, Rössler and Barthel 1998). This process may partially explain the significant presence of pecopterids at this locality, taking into account the presence of volcanic and volcaniclastic rocks interbedded within the deposits of the studied stratigraphic section. However, further studies are needed in order to establish a positive correlation between abundance of Pteridophyta and volcanic activity in Gondwana realm.

\section{CONCLUSIONS}

We confirm the presence of "Glossopteris flora" in the Bolivian Central Andes (west-central South America), represented by the morphogenera Glossopteris, Pecopteris and Asterotheca. Three species of Pecopteris fronds and a fertile specimen of Asterotheca are described herein, and interpreted within the local and regional paleoenvironment. A tropicalsubtropical paleoclimtae is inferred, with relatively warm and semiarid conditions, in agreement with previous paleogeographic interpretations locating the Peru-Bolivia and Paraná basins at low latitudes during the Permian.

\section{ACKNOWLEDGMENTS}

We thank Yacimientos Petrolíferos Ficales Bolivianos (YPFB), Servicio Nacional de Geología y Minería de Bolivia (SERGEOMIN) and ORSTOM Bolivie for logistic support for fieldwork in Bolivia. Suggestions for improvements of the manuscript from Hermann Pfefferkorn and anonymous reviewers are gratefully acknowledged. Research that led this report was partly supported by grants from Ministerio de Educación y Ciencia de España, ORSTOM and Petroleum Research Fund, U.S.A., to EDM, and from Conselho Nacional de Pesquisa (CNPq) to CELV. We are also grateful to Luiz Flávio Lopes, photographer of the Departamento de Paleontologia e Estratigrafia, IG-UFRGS. This report is an updated part of a Master Dissertation by CELV at Universidade Federal do Rio Grande do Sul (UFRGS) and a contribution to the IGCP Project 471.

\section{RESUMO}

Plantas fósseis, pertencentes aos morfo-gêneros Glossopteris, Pecopteris e Asterotheca, foram coletadas na porção superior da seção aflorante da Formação Chutani, próxima ao povoado de San Pablo de Tiquina, sudeste do lago Titicaca (Altiplano norte, Bolívia). Este trabalho analisa folhagens do tipo feto encontradas neste sítio. Entre os espécimes estéreis, três espécies de frondes pecopterídeas foram identificadas: Pecopteris dolianiti, P. cf. cadeadensis e $P$. cf. pedrasica. Todas essas espécies eram até agora restritas aos depósitos permianos da Bacia do Paraná. A despeito do estado de preservação ruim do material, um espécime fértil pôde ser determinado como pertencente ao gênero Asterotheca. Implicações paleoambientais e paleoecológicas deste novo achado são brevemente analisadas.

Palavras-chave: Altiplano Boliviano, Permiano, Pecopteris, Asterotheca. 


\section{REFERENCES}

Anderson JN AND Anderson HM. 1985. Paleoflora of Southern Africa. Prodromus of South African Megafloras, Devonian to Lower Cretaceous. Rotterdam: A. A. Balkema 422p.

Arai M. 1980. Contribuição dos polens estriados na bioestratigrafia neopaleozóica da parte nordeste da Bacia do Paraná. Bol IG-USP 11: 98-105.

Archangelsky S and De La Sota E. 1960. Contribución al conocimiento de las filices pérmicas de Patagonia Extrandina. Act Geol Lilloana 3: 85-126.

Archangelsky S, CÉSARI S And Cúneo NR. 1999. Revisión de Asterotheca golondrinensis Herbst, helecho pérmico de Patagonia, Argentina. In: Simposio ARGentino de Paleobotánica y Palinología, 10., Buenos Aires. Public Esp 6..., Buenos Aires: APA, p. 23-26.

Arens NC. 1991. Vegetation Replacement Following Wildfire Disturbance in Middle Pennsylvanian Clastic Wetlands: Examples from Joggins, Nova Scotia, Canada. In: Geological Society of America. Abstracts..., p. A456.

Arrondo O. 1967. Dizeugotheca branisae n.sp. nueva filice eusporangiada del Pérmico inferior, Bolivia. Rev Mus La Plata (n.s.), Pal 5: 55-61.

Ascarruntz R AND Radelli L. 1964. Geologia della Penisola di Copacabana e delle Isole del settore sud del Lago Titikaka. At. Soc. Italiana Sc. Nat. e Mus. Civ. St. Nat. Milano 103: 273-284.

Barthel M and Weiß H-J. 1997. Xeromorphe baumfarne im Rotliegend Sachsens. Veröff. Mus Nat Chem 20: 45-56.

Beltan L, Freneix S, Janvier P and López-Paulsen O. 1987. La faune triasique de la formation de Vitiacua dans la région de Villamontes (Département de Chuquisaca, Bolivie). N Jahrb Geol Paläont Mh 2: $99-115$.

Björkman O And Demmig-Adams B. 1995. Regulation of Photosynthetic Light Energy Capture, Conversion, and Dissipation in Leaves of Higher Plants. In: Schulze E-D ANd CAldwell, MM (Eds.), Ecophysiology of Photosyntesis, Berlin-Heidelberg: Springer-Verlag, p. 17-47.

Bortoluzzi CA. 1975. Étude de quelques empreintes de la flore gondwanienne du Brésil. In: Congrès National des Sociétés Savantes, 95(III)., Reims. Actes..., Reims: S. Savantes, p. 171-187.
Boureau E and Doubinger J. 1975. Traité de Paléobotanique: Filicophyta. Masson et Cie., Tome IV, Fasc. 2: Pteridophylla ( $1^{\mathrm{er}}$ partie). Paris: Masson et Cie., 768p.

Branisa L. 1965. Los fósiles guía de Bolivia. Bol Serv Geol de Bolivia 6: 1-280.

Cazzulo-Klepzig M. 1978. Estudo da tafoflórula do Membro Morro Pelado na sua localidade-tipo. Pesquisas 11: 225-303.

Cutter EG. 1987. Anatomia Vegetal. Parte II - Órgãos, Experimentos e Interpretação. São Paulo: Roca. $336 \mathrm{p}$.

DaEmon RF ANd QuAdros LP. 1970. Bioestratigrafia do Neopaleozóico da Bacia do Paraná. In: Congresso Brasileiro de Geologia, 24. Brasília, Anais..., Brasília: SBG, 1970, p. 359-412.

Dalenz A And Merino D. 1994. Comportamiento asociativo y bioestratigrafía de la Formación Copacabana de los departamentos de Cochabamba y oeste de Santa Cruz. In: Congreso GeolóGico De BoLivia, 11. Santa Cruz, Memorias..., Santa Cruz: SGB, 1994, p. 186-198.

De La Sota E And Archangelsky S. 1962. Dos nuevas especies de "Asterotheca" de la série Triásica "El Tranquilo', Provincia de Santa Cruz. Ameghiniana 2: 113-119.

DíAz-Martínez E. 1995. Regional correlations with Late Paleozoic events in Bolivia. In: Simposio sobre Cronoestratigrafía da Bacia do Paraná, 2. Porto Alegre, Bol Res Exp..., Porto Alegre: SBG, 1995, p. 98-100.

DíAz-Martínez E. 1996. Síntesis estratigráfica y geodinámica del Carbonífero de Bolivia. In: CoNGreso Geológico de Bolivia, 12. Tarija, Memorias..., Tarija: SGB, 1996, p. 355-367.

DíAz-MARTínez E. 1999. Estratigrafía y paleogeografía del Paleozoico superior del norte de los Andes Centrales (Bolivia y sur del Perú). In: Macharé J, Benavides V and Rosas S (Eds.), 75 Aniversario Sociedad Geológica del Perú, Lima: SGP, Volumen Jubilar $n^{\circ} 5$, p. 19-26.

Díaz-Martínez E, IsaAcson PE and Sablock PE. 1993. Late Paleozoic latitudinal shift of Gondwana: stratigraphic/sedimentologic and biogeographic evidence from Bolivia. Doc Lab Géol Lyon 125: 119-138. 
Díaz-Martínez E, Sempere T, IsaAcson PE And Grader G. 2000a. Paleozoic of western Gondwana active margin (Bolivian Andes). In: INTERNATIONAL Geological Congress, 31., Rio de Janeiro. PreCongress Fieldtrip Bft 27..., Rio de Janeiro, 31p.

Díaz-Martínez E, Mamet B, IsaAcson PE AND Grader GW. 2000b. Permian marine sedimentation in northern Chile: new paleontological evidence from the Juan de Morales Formation and regional paleogeographic implications. J S Am Earth Sci 13: 511-525.

DiMichele WA And Hook RW. 1992. Paleozoic Terrestrial Ecosystems. In: BeHRENSMEYER ET AL. (Eds.), Terrestrial Ecosystems Through Time Evolutionary Paleoecology of Terrestrial Plants and Animals, Chicago and London: Chicago Press, p. 205-325.

Dolianiti E. 1957. Eupecopteris no Gondwana do Rio Grande do Sul. Bol Soc Bras Geol 6: 60-67.

Frenguelli J. 1953. Las Pecopterídeas del Pérmico de Chubut. Not Mus La Plata 16 (Paleont 99): 287-296.

Gartner BL. 1995. Plant Stems: physiology and functional morphology. San Diego: Academic Press. 440p.

Givnish TJ. 1987. Comparative studies of leaf form: assessing the relative roles of selective pressures and phylogenetic constraints. N Phytologist 106 (Supl.): 131-160.

Givnish TJ. 1988. Adaptation to sun and shade: a wholeplant perspective. Australian J Plant Phys 15: 63-92.

Givnish TJ. 1995. Plant Stems: Biomechanical Adaptation for Energy Capture and Influence on Species Distributions. In: Gartner BL (Ed.), Plant Stems Physiology and Functional Morphology, New York: N Y Acad Press, p 3-49.

Herbst R. 1976. Asterotheca golondrinensis n.sp. from the lower Permian Golondrina Series of the Bajo De La Leona, Santa Cruz, Argentina. Palaeobotanist 25: 126-129.

IANNuZzi R, Vieira CEL, Guerra-Sommer M, DíaZMartinez E and Grader G. 2004. Permian plants from the Chutani Formation (Titicaca Group, Northern Altiplano of Bolivia): II. the morphogenus Glossopteris. An Acad Bras Cienc 76: 129-138.

IsAacson PE AND DíAz-Martínez E. 1995. Evidence for a Middle-Late Paleozoic Foreland Basin and Sig- nificant Paleolatitudinal Shift, Central Andes. In: TANKard AJ, SuÁrez-Soruco R ANd Welsink HJ (Eds.), Petroleum Basins of South America: AAPG, p. 231-249. Memoir 62.

Isaacson PE, Palmer BA, Mamet BL, Cooke JC AND SANDERS DE. 1995. Devonian-Carboniferous stratigraphy in the Madre de Dios basin, Bolivia: Pando X-1 and Manuripi X-1 wells. In: TANKARD AJ, Suárez-Soruco R and Welsink HJ (Eds.), Petroleum Basins of South America: AAPG, p. 501510. Memoir 62.

LARCher W. 1995. Physiological Plant Ecology: ecophysiological and stress physiology of functional groups. Springer-Verlag, 3a ed., Berlin, 506p.

Lösch R AND Schulze E-D. 1995. Internal Coordination of Plants Responses to Drought and Evaporational Demand. In: Schulze E.-D. AND Caldwell MM (eds.). Ecophysiology of Photosyntesis. SpringerVerlag, Berlin-Heidelberg, p. 185-204.

Mamet BL. 1994. Algues calcaires marines du Paléozoïque Supérieur (Equateur, Bolivie). Ann Soc Géol Belg 117: 155-167.

Mamet BL. 1996. Late Paleozoic small foraminifers (endothyrids) from South America (Ecuador and Bolivia). Can J Earth Sci 33: 452-459.

Mamet BL and Isaacson P. 1997. Bashkirian (Early Pennsylvanian) small foraminifers from Bolivia. In: Congr Int Strat Géol Carbonifère et PerMIEN, 13. Prace, Proceedings..., Prace: sect. 2C, p. 319-328.

Marques-Toigo M. 1991. Palynobiostratigraphy of the southern Brazilian Neopalaeozoic Gondwana Sequence. In: International Gondwana SympoSIUM, 7. São Paulo, Proceedings..., São Paulo: IGUSP, p. 503-515.

Menendez CA. 1957. "Asterotheca hilariensis" sp. nov. del Triásico superior de Hilário, San Juan. Ameghiniana 1: 25-30.

Merino D and Blanco J. 1990. Conodontos de la Formación Copacabana (Carbonífero superior-Pérmico inferior) en la sección de Huarachani-Pacobamba, Departamento de La Paz, Bolivia. Rev Téc YPFB 11: $105-116$.

Morel P ANd Irving EC. 1981. Tentative paleocontinetal maps for the Early Phanerozoic and Proterozoic. J Geology 86: 195-198. 
OdReman O AND RicARdi F. 1992. Flora paleozoica de la Regíon de Carache, Estado Trujillo, Venezuela. Bol Soc Venez Geól 45: 33-41.

Oliveira D. 1996. Estudo das Samambaias Férteis do Paraná. São Paulo. Universidade Estadual de São Paulo, 1996, 63p. Graduated Monography.

Oller J And Sempere T. 1990. A fluvio-eolian sequence of probable Middle Triassic-Jurassic age in both Andean and Subandean Bolivia. In: Symposium INTERNAtional "GeodynamiQue Andine", 1., Grenoble. Rés Communic..., Grenoble: p. 237-240.

Read CB. 1941. Plantas Fósseis do Neopaleozóico do Paraná e Santa Catarina, Brasil. Ministério da Agricultura, Divisão de Geologia e Mineralogia, Monografia n. 12. Rio de Janeiro: 1941, 112p.

Rigby JF. 1968. New fossil locality near Laras, State of São Paulo. In: Congresso Brasileiro de GeoloGIA, 22. Belo Horizonte, Anais..., Belo Horizonte: SBG, 1968 , p. 201-208.

RoHN R AND RöSLER O. 1986. Pteridófilas pecopteróides da Formação Rio do Rasto no Estado do Paraná e da Formação Estrada Nova no Estado de São Paulo (Bacia do Paraná, Permiano Superior). Bol IG-USP 17: 57-76.

RöSLER O. 1972. Flora da Formação Rio Bonito no Estado do Paraná. São Paulo. Universidade de São Paulo, Instituto de Geociências, 130p. Doctor Thesis.

Rössler R AND BARThel M. 1998. Rotliegend Taphocenoses Preservation Favoured by Rhyolithic Explosive Volcanism. Freiberger Forsch 474: 59-101.

SAKAgami S. 1995. Upper Paleozoic bryozoans from the Lake Titicaca region, Bolivia. Trans Proc Palaeont Soc Japan 180(NS): 226-281.

Sakagami S and Mizuno Y. 1994. Discovery of middle Pennsylvanian fusulinaceans and conodonts from the Copacabana Group in the Lake Titicaca region, Bolivia. Trans Proc Palaeont Soc Japan 174(NS): 484-494.
SEMPERE T. 1995. Phanerozoic Evolution of Bolivia and Adjacent Regions. In: TANKARD AJ, SuÁreZSoruco R AND Welsink HJ (Eds.), Petroleum Basins of South America: AAPG, p. 207-230. Memoir 62.

Sempere T, Herail G, Oller J and Bonhomme MG. 1990. Late Oligocene-Early Miocene major tectonic crisis and related basins in Bolivia. Geology 18: 946-949.

Sempere T, Aguilera E, Doubinger J, Janvier P, Lobo J, Oller J and Wenz S. 1992. La Formation de Vitiacua (Permien moyen à supérieur - Trias ?inférieur, Bolivie du Sud): stratigraphie, palynologie et paléontologie. N Jahr Geol Paläont Abh 185: 239-253.

Scotese CR AND McKerrow WS. 1990. Revised world maps an introduction. In: McKerrow WS AND Scotese CR (Eds.) Paleozoic Paleogeography and Biogeography, London: Geol Soc London, p. 1-21. Memoir 12.

Soler P And Sempere T. 1993. Stratigraphie, géochimie et signification paléotectonique des roches volcaniques basiques mésozoïques des Andes boliviennes. CR Acad Science Paris 316 (série II/6): 777-784.

SPICER RA. 1989. Physiological characteristics of land plants in relation to environment through time. Trans R Soc Edinburgh (Earth Sc) 80: 321-329.

SuÁrez-Riglos M And Dalenz A. 1993. Pteriomorpha (Bivalvia) noriano de la Formación Vitiacua del área de Villamontes (Tarija). Rev Téc YPFB 13/14: 155160.

Suárez-Soruco R and Díaz-Martínez E. 1996. Léxico Estratigráfico de Bolivia. Rev Téc YPFB 17: $1-213$.

Vieira CEL and IAnnuzzi R. 2000. Presença de Pecopteris e Asterotheca no afloramento Morro do Papaléo, município de Mariana Pimentel, Rio Grande do Sul (Formação Rio Bonito, Eopermiano da Bacia do Paraná). Pesquisas 27: 49-64. 